\title{
Information literacy as a tool to support political participation
}

\author{
Lauren Smith
}

\begin{abstract}
Recent political events have raised the profile of information literacy as a potential tool for supporting informed political participation. This article emphasises the importance of supporting political engagement through information provision and information literacy development, drawing on findings from two research projects to discuss what information needs young people have in relation to political engagement and identify some examples of work taking place in Scottish school libraries to help young people develop political knowledge and feel able to participate meaningfully in democratic processes. Some of the main barriers to libraries engaging with this work are also discussed.
\end{abstract}

\section{Introduction}

Although the library and information profession has long spoken about the democratic role of libraries (Kranich, 2001), discussions around the role of libraries and librarians in promoting active citizenship, supporting democratic engagement and safeguarding individuals' rights have not been quite so prominent as they are currently, in the aftermath of the EU Referendum, as well as the Scottish Independence Referendum and the 2015 General Election. There has been much conjecture over whether or not the outcomes of these events would have been different if the general public were better able to navigate the large amount of information of differing quality (Goldstein, 2016), and whether people are sufficiently able to make informed decisions about how they vote based on their ability to assess the information they encounter to help it shape their perspectives. The degree to which Leave voters in the EU Referendum now regret their decision and feel it was based on a lack of knowledge, and believing inaccurate or deliberately false information is also in question (Somin, 2016). Additionally, the franchise of young people has been discussed, with some political parties and other groups pushing for the extension of the right to vote to 16 and 17 year olds (Lucas, 2016).

\section{Author}

Lauren Smith is a Research Associate in the School of Education at the University of Strathclyde.

Email: lauren.n.smith@strath.ac.uk

Received 25 July 2016

Accepted 02 November 2016 
Young people's political engagement is also a focus of educational discourse, for example the Contemporary Childhood Conference 2016 is focusing on Young Citizens \& Society: Fostering Civic Participation. A number of international conferences in the field of library and information science (LIS) are this year focusing on how the profession can support access to information, knowledge and understanding of political issues and events, and participation in democratic processes (for example ECIL 2016). There is interest in how information can be provided in targeted ways to help people of all ages to advocate for their needs and rights, and how information literacy can be provided to support not only academic attainment but everyday life skills, including those of citizenship.

The interest in how the library and information profession can support these areas of public life is not surprising; we have recently experienced three significant political events - the 2014 Scottish Independence Referendum, the 2015 General Election and the 2016 European Referendum. It is natural for the information profession to consider how we as information providers can ensure people are knowledgeable about these events, particularly when there is widespread concern that people, and young people in particular, are struggling with general disinterest (Henn and Foard, 2011), mistrust of politicians and disillusionment with the democratic process (Ibid) information overload (Husain, 2016), and/or a lack of information seeking skills (Crane, 2005). While some of these problems are systemic and are not obvious territory for the library and information profession to address, issues of locating and making sense of information are clearly within our remit.

Supporting younger citizens to participate in politics is the area of this work I am particularly interested in. Popular conceptions of young people as 'voters of the future' are not accurate in our current context; for example, in the Scottish Independence Referendum, the vote was extended to 16 and 17 year olds, and it is crucial for people of this age group to be able to make informed choices with their right to vote. Even before this, supporting teenagers' political development has been viewed as an important aspect of a strong democratic system. The political participation of young people is important for the functioning of a democratic society; not only because they are voters and leaders of the future, but because they are citizens in their own right. Indeed, a great deal of responsibility is often placed on young people and their engagement with democratic systems. They are often blamed for weaknesses in democracy due to declining levels of participation (Amnå, 2012; Putnam, 2000).

Although there is much discussion of a youth 'democratic deficit', the Joseph Rowntree Foundation argued in their research into young people's politics that it is not possible to evaluate whether this generation of young people is more disenchanted with politics than previous generations, and suggest that concern about a 'democratic deficit' are misplaced. Although young people are less likely to vote than older citizens, they have been found to participate in politics in a broad range of other ways (Loader et al., 2014), which indicates that engagement with politics may not be as significant a problem as non-participation in voting specifically. In contrast to suggestions that there is a democratic deficit with regard to young people's participation, much research has found that young people are in fact more civically and politically minded than young people of 
previous generations, which is evidenced by higher levels of volunteering, charitable donations, and interest and involvement in non-formal and single-issue political causes (Loader, 2007). A number of studies have also found that young people prefer less formal methods of political engagement (Schwarzer 2011; Benton et al. 2008; Dalton, 2006). Alongside the statistics for turnout among young people in recent elections and referendums (McIntyre, 2015), the evidence indicates that in the UK, youth political engagement is stronger than is often assumed. What is less clear, however, is whether young people are able to find, evaluate and use information successfully to make informed decisions relating to however they choose to engage in political life.

Addressing this gap in knowledge has been the focus of two of my recent research projects; as well as recently having completed doctoral research into the political information experiences of young people (Smith, 2013), I was a fortunate recipient of a research bursary from the CILIP Information Literacy Group, which enabled me to conduct a small-scale research project into the ways in which school libraries in Scotland provided information and information literacy support to young people in the run up to the Scottish Independence Referendum and the General Election. Although two very different events, the findings indicated that young people's information needs around politics are broad, and that it is often extremely difficult to address these information needs. Some of the barriers relate to the complexity of the issues and a lack of appropriate resources, but I believe that some barriers related more closely to a lack of willingness on the part of schools and councils to fully engage with the political development of their young citizens. As intellectually curious individuals, the young people under consideration in both of the studies often asked about the perspectives of their teachers and librarians. People are the first port of call for many information needs, and politics is no different. However, teachers and librarians are limited as to how they can respond to pupils, and there are concerns around the dangers of 'brainwashing' young people into the worldviews of their gatekeepers. The fear of having an unfair influence on young people, however, may extend too far when it comes to how we run our school libraries. Policies and ideas around best practice within the education system appear to be based on extreme caution - it is hard to blame library staff for avoiding engaging in any level of political education of pupils when the consequences of providing political information or sharing opinions may be severe. There is also a lack of understanding of the difference between the concepts of 'neutrality' and 'impartiality'; it is possible for librarians and teachers to engage in non-neutral political education and other pedagogical activities at the same time as maintaining impartiality and supporting young people to develop their own informed opinions.

This avoidance of engagement with political education is at odds not only with the professional responsibility of library and information workers to provide access to information and support intellectual freedom, but also with the curricular agendas within the UK. The Scottish Curriculum for Excellence has a set of themes across the whole curriculum, one of which is Global Citizenship. This theme includes 'education for citizenship', which 'encourages taking thoughtful and responsible action, locally and globally' (Education Scotland, 2016). The National Curriculum for England also includes formal citizenship education (Department for 
Education, 2013). The engagement with the citizenship elements of the curriculums I identified within my two studies was limited, and worked around the edges, rather than fully embracing work to explicitly support the development of young people as knowledgeable, participative and engaged citizens. Where schools and councils are reluctant to allow discussion and debate of political issues between pupils and their educators, pupils feel this limits their ability to learn what they feel they need to - the various sides of the issues they encounter in the media on a daily basis and where they stand on the issues. The implications for young people who do not have the opportunity to discuss political issues in a balanced way concern me; whereas some home environments do provide the opportunity for nuanced discussion around employment, welfare and immigration, for example, others do not. A study conducted by Eichhorn et al. (2014) found that young people who discussed the referendum with their parents did not feel more confident having done so, but that where they discussed the referendum at school, their confidence increased. The authors argue that discussing politics in the classroom in an informed manner is a crucial element of political participation, and that there is "no other institution that seems to be able to create the same positive effect on political confidence." (Eichhorn, 2014)

Librarians in my CILIP ILG study reported how many pupils seeking information search quickly, struggle to select keywords, often do not look beyond the first few search results and find assessing reliability of results very difficult. Support is needed to help young people navigate the abundance of information available to them and to develop the critical skills needed to evaluate and use it to develop their own perspectives.

\section{Political education does not meet young people's needs}

Young people across the UK feel unsupported by schools in terms of their political education. Although political education is part of both the Curriculum for Excellence in Scotland and the National Curriculum in England, the young people I have spoken to as part of my research do not find this education to be sufficient for them to understand how the political process works, what their role in it is, and how they can make informed choices. The limitations of school-based political education have been echoed by Mackie (2016), who argues that "the political education young people largely receive is not political at all", highlighting its focus on social responsibilities and the encouragement of 'pro-social' behaviour. Where education does look at politics rather than a broader conception of citizenship, it tends to focus on the formalities of the system rather than teaching young people "how to do politics". The 14 and 15 year olds I worked with during my doctoral research talked about the limitations they find in their political education, and how they wished their teachers would tell them not only about how Westminster government functions, but also about what 'left' and 'right' means, what the difference between Labour and Conservative is, and how they could identify what political party their views are most closely aligned with. As well as suggesting formal lessons, the pupils suggested informal conversations with teachers and help with finding information as ways they could learn about these issues. These are clear examples of gaps in the political knowledge of teenagers 
and their identification of their own learning needs, as well as potential solutions to this problem.

Beyond formal political education, young people also feel unsupported by their formal educational experiences. As my doctoral research revealed, teenagers use a wide variety of sources of information to become politically informed, many of which they encounter passively. When they actively seek information, they report feeling unsure about where to find reliable and trustworthy information. Instead, they often seek support from trusted authority figures, including parents and other family members, teachers and librarians. However, they often experience frustration when they find they either cannot trust their family members to present a balanced representation of a political issue, or they are not sufficiently informed to help them.

The problems young people experience associated with becoming politically knowledgeable extend to their encounters with school libraries and librarians. Although many young people reported that they trust teachers and librarians to give them balanced and accurate information, they often experience frustration when these individuals refuse to engage in discussion with them. I also encountered these issues in Scotland, when conducting research with school librarians. School librarians are asked for information, thoughts and opinions. They reported that pupils have a wide range of information in relation to political participation. Questions asked of library staff included why political events were happening, how they could participate, what the outcomes of the events may be, and how the outcomes may affect their own lives. Some young people seek specific information about political parties and ideologies, and resources pitched at an appropriate level for secondary school aged children can be difficult to locate. Additionally, several participants reported that they feel limited as to how much they can support these requests. Nevertheless, many librarians reported helping young people to meet these information needs.

Some librarians reported specifically supporting political literacy development in the run up to the Referendum and the Election. Additionally, information literacy support and some other forms of information are provided by many libraries all year round. Some of the information provided included specially designed displays and information resources, books and other library stock, and the inclusion of relevant political topics in information literacy activities to support classroom topics. The examples provided by participants were encouraging and indicate some level of appetite from school librarians in Scotland to engage in political education.

\section{Reluctance to support political participation through information provision and information literacy}

My research findings indicate that some libraries have been able to lead or take part in a number of activities which explicitly promote the development of political knowledge and participation, with the support of their local authorities and other bodies. This suggests that this kind of activity is within the accepted remit of school libraries, and that where it is presently believed to not be, there is the potential for discussion around the issues. However, several of my participants 
reported reluctance to support political participation through information provision and information literacy, sometimes due to a lack of confidence and knowledge and sometimes due to not feeling it is the role of school libraries to engage in political education. Others reported that although personally they were very keen to engage in work of this nature, they encounter significant barriers, including a lack of time and resources, a lack of engagement from the school as a whole, risk aversion from schools and councils as well as a lack of guidance around what kind of engagement with political education would be appropriate. These are significant barriers and may explain the overall lack of engagement from school libraries with political education and support for active citizenship that can be observed in schools across the UK.

\section{Conclusion}

Young people want to learn about, be involved in and influence politics. It is important for them to be included in the political domain, as the citizens they are now, not just in the future, to enrich overall political debate. However, as with any group, they need resources and support to do this. To be able to support the citizenship agendas of local and national government, schools need to provide access to information, guidance and support with information seeking and developing knowledge using the information they encounter, and spaces and opportunities for pupils to discuss, debate and develop their political understanding and opinions.

School libraries and librarians are excellently placed to support pupils to develop the knowledge and abilities to participate in politics, but face many barriers to doing so. My research into Scottish school libraries indicates that there is a significant lack of resources and a lack of relevant training, not to mention that a number of schools do not employ a professional librarian, and several have no library service at all. Where library staff do try to engage in work around political education, they often face difficulties around clarity about appropriate conduct in the eyes of local authorities, and apparent conflicts of interest between the professional values of librarianship and the perceived limitations in schools relating to the political education of young people. Standardised and consistent guidance from the Scottish Government for education services around what can and cannot be done around election time and generally would go a long way to providing the necessary clarity. There is also a key role for CILIP and CILIPS, who could offer valuable guidance, drawing on professional ethics and values. Discussion around what the role of school (and other sectors of) libraries should be in terms of balancing freedom of expression and access to information alongside ensuring the safety and wellbeing of vulnerable groups, including children, is of key importance for the profession. Practice should be based on the contexts of specific schools and their communities, but this practice must be guided and justified by a strong articulation of professional values and priorities. To determine what these values and priorities are, discussion between professional networks such as the CILIP school libraries group and the School Library Association is much needed. 


\section{Further Research}

Although it is difficult in to conduct comparative studies of educational interventions such as information literacy instruction, this may be a useful direction for future research. Methods such as randomised controlled trials may be a way to identify effective ways of providing political education, including information literacy support and information provision in libraries. A potentially informative area for further investigation may be to identify which activities taking place through school libraries are the most effective in supporting the development of political knowledge and ability to locate, understand, critique and effectively use political information. This could form the basis of an evidencebased set of recommendations for supporting informed citizenship in schools and elsewhere. This may contribute to the demands being made by political figures for 'proof' that school libraries can and/or do have an impact on pupil attainment and development. Further research would ideally build on the large international body of quantitative (and qualitative) evidence of the positive impact of school libraries on attainment, literacy and learning, with the inclusion of all areas of the Curriculum for Excellence, including Global Citizenship. There has not yet been a quantitative assessment of the impact of Scottish school libraries (Williams, 2013, 2015) and research should be conducted to address this.

The library staff who participated in this study identified a number of barriers they have experienced or fear they will experience when they seek to engage in supporting pupils' political participation. These barriers relate to personal perceptions, school practice and culture, and policy. However, these barriers were not uniformly reported by all respondents. It may be appropriate for CILIPS and other bodies relating to school libraries to advocate for school libraries' involvement in the elements of education that support pupils' development in relation to citizenship.

Undertaking work of this kind in the current economic and political circumstances will not be easy; funding cuts, understaffing, and deprofessionalisation are all having a significantly detrimental impact on school (and public) library services and limiting their capacity to even properly stock and staff school libraries. However, to meet our professional responsibilities as librarians, and to serve our learning communities with their information and educational needs, we must promote a vision of better and not only preserved services, alongside challenging the present school library cuts. The library and information profession is populated with many excellent, passionate individuals, many of whom work in the school library sector. It is crucial for these individuals to engage, where they can, in professional activity such as involvement in special interest groups and communities of practice (for example the Scottish Information Literacy Community of Practice), to share their experiences and ideas. Collectively, we can better justify the need for the activities we wish to develop and their contribution to a more informed, and hopefully just, society. 


\section{References}

Amnå, E. (2012) How is civic engagement developed over time? Emerging answers from a multidisciplinary field, Journal of Adolescence [online], 35(3), 611-627. URL: http://doi.org/10.1016/j.adolescence.2012.04.011 [accessed 23.07.16].

Crane, J. (2005) A study of the political information seeking behaviour of students. University of Sheffield. URL:

http://dagda.shef.ac.uk/dispub/dissertations/2004-

05/External/Crane Jonty_MScIM.pdf [accessed 23.07.16].

Department for Education (2013) National curriculum in England: citizenship programmes of study. URL:

https://www.gov.uk/government/publications/national-curriculum-in-englandcitizenship-programmes-of-study [accessed 23.07.16].

Education Scotland (2016) Global citizenship.

URL:http://www.educationscotland.gov.uk/learningandteaching/learningacrossthe curriculum/themesacrosslearning/globalcitizenship/index.asp [accessed 23.07.16].

Eichhorn, J. (2014) How lowering the voting age to 16 can be an opportunity to improve youth political engagement - Lessons from the Scottish Independence Referendum. URL: http://www.youthforum.org/assets/2014/04/dpart-Eichhorn16VotingAge-Briefing.pdf [accessed 23.07.16].

Eichhorn, J. et al. (2014) Results from the 2014 survey on 14-17 year old persons living in Scotland on the Scottish independence referendum. URL:

https://www.aqmen.ac.uk/sites/default/files/YoungScotsBriefing060614.pdf [Accessed 23.07.16].

Goldstein, S. (2016) The EU referendum campaign: a case of fateful information illiteracy. CILIP Information Literacy Blog, 17 June 2016. URL:

http://www.informationliteracy.org.uk/2016/06/the-eu-referendum-campaign-acase-of-fateful-information-illiteracy/ [accessed 24.07.16].

Henn, M., \& Foard, N. (2011) Young People, Political Participation and Trust in Britain. Parliamentary Affairs [online], 1-21.URL:

http://doi.org/doi:10.1093/pa/gsr046 [accessed 23.07.16].

Husain, N. (2016) View from abroad: Lies and statistics in the EU referendum. Dawn. URL: http://www.dawn.com/news/1261415 [accessed 14.06.16].

Kranich, N. (2001) Quotes about Libraries and Democracy. URL: http://www.ala.org/aboutala/governance/officers/past/kranich/demo/quotes [accessed 14.06 2016].

Loader, B. D. et al. (2014) The networked young citizen: social media, political participation and civic engagement. Information, Communication \& Society [online], 17(2), 143-150. URL: http://doi.org/10.1080/1369118X.2013.871571 [accessed 14.06.16]. 
Loader, B. D. (2007) Young citizens in the digital age: Political engagement, young people and new media. London: Routledge.

Lucas, C. (2016) Hansard: Electoral reform (proportional representation and reduction of voting age) [online]. 20 July 2016. Volume 613 Column 834. URL: https://hansard.parliament.uk/commons/2016-07-

20/debates/16072027000002/ElectoralReform(ProportionalRepresentationAndRe ductionOfVotingAge) [accessed 24.07.16].

Mackie, I. (2016) Reflections on the Scottish referendum and young people's participation. URL: https://oldmanmackie.wordpress.com/2016/01/22/reflectionson-the-scottish-referendum-and-young-peoples-participation/ [accessed 23.07.16].

McIntyre,S. (2015) General election: Highest turnout since 1997. The Independent [online], 8 May 2015. URL:

http://www.independent.co.uk/news/uk/politics/generalelection/general-election2015-highest-turnout-since-1997-10235076.html [accessed 23.07.16].

Putnam, R. (2000) Bowling Alone: The Collapse and Revival of American Community. New York: Simon and Schuster.

Schwarzer, S. (2011) Political socialization as the driving factor for political engagement and political participation. Paper prepared for the ELECDEM workshop "Advanced Techniques for Political Communication Research: Content Analysis", March 20-24, 2011, Amsterdam. Amsterdam: ELECDEM.

Smith, L. (2013) Critical information literacy instruction for the development of political agency, Journal of Information Literacy, 7(2), 15-32.

Somin, I. (2016) Brexit, "Regrexit," and the impact of political ignorance. Washington Post [online], 26 June 2016. URL:

https://www.washingtonpost.com/news/volokh-conspiracy/wp/2016/06/26/brexitregrexit-and-the-impact-of-political-ignorance/ [accessed 24.07.16].

Williams, D. (2015) Letter in response to Scottish Parliament Public Petitions Committee 24 November 2015 PE01581: Save Scotland's School Libraries. URL: http://doi.org/10.1017/CBO9781107415324.004 [accessed 23.09.16].

Williams, D. (2013) Impact of school libraries on learning. URL: http://scottishlibraries.org/wpcontent/uploads/2015/05/SLIC_RGU_Impact_of_School_Libraries_2013.pdf [Accessed 23.07.16].

\section{Acknowledgement}

Grateful acknowledgement is given to the Economic and Social Research Council for doctoral funding (grant no: 17435RS4729) and the CILIP Information Literacy Group for the Research Bursary that enabled the research discussed in this report to be conducted. 


\section{Open access and copyright}

Library and Information Research is an open access journal. A freely available copy of this paper may be downloaded from the journal's website: http://www.lirgjournal.org.uk.

Copyright and associated moral rights in works published in Library and Information Research are retained by the author(s) but this paper may be used freely, with proper attribution, in educational and other non-commercial settings. 